\title{
3,4-DIHYDROXYBENZOIC ACID AND 3,4-DIHYDROXYBENZALDEHYDE FROM THE FERN Trichomanes chinense L.; ISOLATION, ANTIMICROBIAL AND ANTIOXIDANT PROPERTIES
}

\author{
Nova Syafni, Deddi Prima Putra, and Dayar Arbain* \\ Faculty of Pharmacy/Sumatran Biota Laboratory, Andalas University, \\ Kampus Limau Manis, Padang, 25163, West Sumatera, Indonesia
}

Received May 1, 2012; Accepted September 5, 2012

\begin{abstract}
3,4-dihydroxybenzoic acid (1) and 3,4-dihydroxybenzaldehyde (2) have been isolated from ethyl acetate fraction of methanolic fractions of leaves, stems and roots of the fern Trichomanes chinense L. (Hymenophyllaceae). These two compounds also showed significant antioxidant using DPPH and antimicrobial activities using the disc diffusion assay.
\end{abstract}

Keywords: Trichomanes chinense L.; 3,4-dihydroxybenzoic acid; 3,4-dihydroxybenzaldehyde; antioxidant; antimicrobial

\section{ABSTRAK}

Telah diisolasi asam 3,4-dihidroksibenzoat (1) dan 3,4-dihidroksibenzaldehid (2) dari fraksi etil asetat ekstrak metanol daun, batang dan akar paku Trichomanes chinense L. (Hymenophyllaceae). Kedua senyawa ini memperlihatkan sifat antioksidan yang signifikan ketika diuji dengan metoda DPPH dan antimiokroba ketika diuji dengan metoda diffusi agar.

Kata Kunci: Trichomanes chinense L.; asam 3,4-dihidroksibenzoat (1); 3,4-dihidroksibenzaldehid (2); antioksidan; antimikroba

\section{INTRODUCTION}

Based on a study on fossils particularly on that of Polypodiaceous family, it was considered that ferns have inhabited the earth as one of the pioneering plants since the ancient time [1]. It was estimated that there were more than 12,000 ferns in the world and more than 3,000 species were found in Indonesia [2]. However, researches on ferns in Indonesia particularly on their chemical constituents are still very limited. So far, only few reports are available on their botanical work [3] while from the chemical point of few there is only one report available on the constituent of Gleichenia linearis (Burm.) Clarke. [4].

Some ferns have been recorded as folk medicines in some countries such as in India, China and Greece [5]. In Indonesia, Diplazium esculentum Swartz [6], Asplenium prolongatum Hook, Lindsaea orbiculata (Lamk.) Mett., Microsorium fortune (Moore) Ching, $M$. buergerianum (Miq.) Ching., Neottopteris nidus (L.) J. Smith, Nephrolepis cordifolia (L.) Presl., Pteris ensiformis Burm. (all Polypodiaceae), Lycopodium cernuum L, (Lycopodinaceae), Dicranopteris dichotoma (Thunb.) Bernh. (Gleicheniaceae), Lygodium japonicum (Thunb.) SW, Lygodium scandens (L.) SW,
(Schizaeacee), Selaginella doederlinii Hieron, S. tamariscina (Bauv.) Spring, S. unsinata (Desv.) Spring. (Sellaginellaceae) are also recorded to have medicinal properties [7-8]. In continuation of our study on Sumatran ferns [6], chemical study, antimicrobial and antioxidant properties of $T$. chinense is described.

Preliminary studies on $T$. chinense indicated that methanolic extract and ethyl acetate fraction showed significant antioxidant activities as well as antimicrobial toward Escherichia coli. In the present work, two major secondary metabolites have been isolated from the ethyl acetate fractions of methanolic extract of the leaves, stems and roots of $T$. chinense. Based on their spectroscopic data both have been identified as 3,4dihydroxybenzoic acid (1) and 3,4dihydroxybenzaldehyde (2). These compounds have previously been found in Malaysian fern Odontosoria chinensis (Dennstaedtiaceae) [9]. Compound (1) have been found in Chinese ferns Cibotium barometz (L.) (Dicksoniaceae) and Stenoloma chusanum (L.) (Polypodiaceae) [10], in flowering plant; Ilex chinensis Sims (Aquifoliaceae) [11], Hibiscus sabdariffa L. (Malvaceae) [12]. The presence of compound (2) have been reported from mushroom Phellinus gilvus (Schwein) Pat. (Hymenochaetaceae) [13], Orchid

* Corresponding author. Tel/Fax : +62-751-71682/770057

Email address : d.arbain@ffarmasi.unand.ac.id

Nova Syafni et al. 
Cremastra appendiculata (D. Don) Makino (Orchidaceae) [14] and leaves of Vitis vinifera L. (Vitaceae) [15].

\section{EXPERIMENTAL SECTION}

\section{Materials}

Plant material: $T$. chinense was collected in Alahan Panjang, Solok District, West Sumatra in May 2011. Herbarium specimen (F02) was identified by Dr. Ardinis Arbain from Herbarium Andalas University (ANDA) and Dr. Arif Hidayat from Herbarium Bogoriense (BO) and lodged at both herbaria. Sample were divided into three parts; leaves, stems and roots.

Testing microbes: Escherichia coli ATCC 25922 NCTC 1224, Staphylococcus aureus ATCC 25923, Vibrio cholera Inaba and Salmonella thypimurium ATCC 14028 NCTCC 12023 were provided by Indonesian Food and Drug Administration (BPOM) Padang Office and pre cultured before being used.

Another materials are methanol p.a (Merck), nutrient agar (NA) (Merck), paper disc (Whatman), dimethyl sulfoxide (DMSO) (Merck), chloramphenicol (Sigma), and DPPH (2,2-diphenyl-1-picrylhydrazyl) free radical (Sigma).

\section{Instrumentation}

Melting points were measured on a Sybron Thermolyne Melting Point Apparatus MP-12615 and are uncorrected, FT-IR spectra on Perkin Elmer FT-IR Spectrum One Spectrophotometer. UV spectra recorded on Shimadzu Spectrophotometer UV-VIS Pharmaspec 1700 , the ${ }^{1} \mathrm{H}$ and ${ }^{13} \mathrm{C}-\mathrm{NMR}$ spectra were measured using Bruker DMX 500 instruments $\left(500 \mathrm{MHz}\right.$ for ${ }^{1} \mathrm{H}$ and $125 \mathrm{MHz}$ for $\left.{ }^{13} \mathrm{C}\right)$. Mass spectra were obtained on a Varian MAT 311 mass spectrometer for electron spray and a Micromass ZABSpecTOF mass spectrometer. TLC was carried out using silica gel 60F254 (Merck) and visualized under UV light (254 nm). Column chromatography was performed on silica gel 60 (0.063-0.200 nm) (Merck). Radial chromatography was performed on silica gel $60 \mathrm{PF}_{254}$ containing gypsum (Merck).

\section{Procedure}

\section{Extraction and isolation}

Air dried samples of $T$. chinense (leaves $(6.0 \mathrm{~kg})$, stems $(4.3 \mathrm{~kg})$ and roots $(1.5 \mathrm{~kg})$ ) were macerated separately with $\mathrm{MeOH}$ for 5 days. After separation of solvents the process was repeated twice more. The combined methanolic extracts were evaporated in vacuo to give thick methanolic extracts. Water was added up to $1 \mathrm{~L}$ then fractionated in turn with hexane, EtOAc and butanol respectively and evaporated in vacuo to give fractions of hexane (leaves $67.6 \mathrm{~g}$, stems $16.0 \mathrm{~g}$, roots $7.0 \mathrm{~g}$ ), EtOAc (leaves $69 \mathrm{~g}$, stems $31.4 \mathrm{~g}$, roots $10.7 \mathrm{~g}$ ) and butanol (leaves $351.0 \mathrm{~g}$, stems $53.2 \mathrm{~g}$, roots $14.0 \mathrm{~g}$ ) respectively. The EtOAc fractions (leaves, stems and roots: $60.0 \mathrm{~g}, 25.0 \mathrm{~g}$ and $10.0 \mathrm{~g}$ respectively) were preadsorbed on $\mathrm{SiO}_{2}$ then column chromatographed on the same adsorbent and eluted with step gradient polarity solvents started from hexane, hexane:EtOAc, EtOAc and EtOAc:MeOH to give series of two major spots on TLC. These were combined, evaporated and then radial chromatographed with an increasing amount of EtOAc in hexane.

The more polar series were combined, evaporated then crystallized from EtOAc-hexane to give reddish brown plates (100 $\mathrm{mg}$ from leaves (0.02\% from dry weight), $22 \mathrm{mg}$ from stems $(0.0028 \%$ from dry weight) and $2 \mathrm{mg}$ from roots $(0.0003 \%$ from dry weight)). Based on its spectroscopic data this compound was identified as 3,4-dihydroxybenzoic acid (1), Mp: $198^{\circ} \mathrm{C}, \quad$ UV $\lambda_{\max }(\log \varepsilon): 294.2 \mathrm{~nm}$ (3.628),

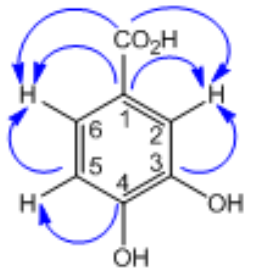

Fig1. HMBC-correlation of (1)

Table 1. NMR data of 3,4-dihydroxybenzoic acid (1) and 3,4-dihydroxybenzaldehyde (2)

\begin{tabular}{|c|c|c|c|c|}
\hline \multirow[b]{2}{*}{ No. } & \multicolumn{2}{|r|}{ Compound 1} & \multicolumn{2}{|r|}{ Compound 2} \\
\hline & ${ }^{13} \mathrm{C}-\mathrm{NMR}$ & $\begin{array}{c}{ }^{1} \mathrm{H}-\mathrm{NMR} \\
\delta_{\mathrm{H}}, \text { multiplicity, coupling }\end{array}$ & ${ }^{13} \mathrm{C}-\mathrm{NMR}$ & $\begin{array}{c}{ }^{1} \mathrm{H}-\mathrm{NMR} \\
\delta_{\mathrm{H}}, \text { multiplicity, coupling }\end{array}$ \\
\hline 1 & 123.28 & - & 124.59 & - \\
\hline 2 & 117.85 & $7.44,1 \mathrm{H}, \mathrm{d}, \mathrm{J}_{2,6}=2 \mathrm{~Hz}$ & 115.21 & $7.44,1 \mathrm{H}, \mathrm{d}, \mathrm{J}_{2,6}=2 \mathrm{~Hz}$ \\
\hline 3 & 146.18 & - & 145.44 & - \\
\hline 4 & 151.66 & - & 151.27 & - \\
\hline 5 & 124.03 & $\begin{array}{c}7.42,1 \mathrm{H}, \mathrm{d}, \mathrm{J}_{2.6}=2 \mathrm{~Hz} \\
\mathrm{~J}_{5.6}=6 \mathrm{~Hz}\end{array}$ & 130.13 & $\begin{array}{c}7.42,1 \mathrm{H}, \mathrm{d}, \mathrm{J}_{2.6}=2 \mathrm{~Hz}, \\
\mathrm{~J}_{5.6}=6 \mathrm{~Hz}\end{array}$ \\
\hline 6 & 115.89 & $6.79,1 \mathrm{H}, \mathrm{d}, \mathrm{J}_{5.6}=6 \mathrm{~Hz}$ & 114.22 & $7.00,1 \mathrm{H}, \mathrm{d}, \mathrm{J}_{5.6}=6 \mathrm{~Hz}$ \\
\hline $\mathrm{C}=\mathrm{O}$ & 170.38 & - & 190.26 & - \\
\hline
\end{tabular}


IR (KBr): 3210.73, 1675.42, 1299.78, $1096.45 \mathrm{~cm}^{-1}$, molecular ion at $\mathrm{m} / \mathrm{z}(\%)=154.0267, \mathrm{C}_{7} \mathrm{H}_{6} \mathrm{O}_{4} \cdot{ }^{13} \mathrm{C}$ and ${ }^{1} \mathrm{H}-\mathrm{NMR}$ data of compound 1 (see Table 1 ).

The less polar series yielded compound (2) as colorless needles $(35 \mathrm{mg}$ from leaves $(0.002 \%$ from dry weight), $33 \mathrm{mg}$ from stems ( $0.003 \%$ from dry weight) and $8 \mathrm{mg}$ from roots $(0.0007 \%$ from dry weight)). As above, based on its spectroscopic data this compound was identified as 3,4-dihydroxybenzaldehyde (2), Mp: $148{ }^{\circ} \mathrm{C}$, UV $\lambda_{\max }(\log \varepsilon): 312.2 \mathrm{~nm}$ (4.030); $278.2 \mathrm{~nm}$ (4.087); 232 $\mathrm{nm}, \quad \mathrm{IR}(\mathrm{KBr}): 3238.70,1651.83,1589.94,1455.25$, $1304.50,1154.17,877.70,814.16,776.70$ and 755.42 $\mathrm{cm}^{-1}$, molecular ion at $\mathrm{m} / \mathrm{z}(\%)=138.0318, \mathrm{C}_{7} \mathrm{H}_{6} \mathrm{O}_{3} \cdot{ }^{13} \mathrm{C}$ and ${ }^{1} \mathrm{H}-\mathrm{NMR}$ data of compound (2) see Table 1.

\section{Antimicrobial properties}

Before being used each bacterium were grown separately in nutrient agar (NA) (Merck) and incubated at $37{ }^{\circ} \mathrm{C}$ for $24 \mathrm{~h}$. These cultures were used for antimicrobial assay by modified agar disc diffusion method of Kirby and Bauer [16]. Single colony of the respective testing bacterium was transferred into NA medium and incubated for $24 \mathrm{~h}$. Culture suspensions in sterile $\mathrm{NaCl} 0.9 \%$ with $25 \%$ transmittant were swabbed onto their respective agar plate. Each extract and fraction was prepared to the concentration of 200, 100, $50,25,12.5,6.25 \mathrm{mg} / \mathrm{mL}$, while compound 1 and 2 prepared from 2, $1,0.5,0.25,0.125$ and $0.0625 \mathrm{mg} / \mathrm{mL}$ in DMSO. Each $10 \mu \mathrm{L}$ of extract, fraction and compound above was dropped onto paper disc (Whatman, $5 \mathrm{~mm}$ diameter) and carefully placed on the culture suspensions for cultivation plate. Control disc contained chloramphenicol $30 \mu \mathrm{g} / \mathrm{mL}$ was similarly prepared in DMSO. Each plate was incubated at $37{ }^{\circ} \mathrm{C}$ for $24 \mathrm{~h}$. Inhibition zones (including the diameter of disc) were measured and recorded.

\section{Antioxidant properties [17]}

$2 \mathrm{mg}$ DPPH free radical was dissolved in $100 \mathrm{~mL}$ $\mathrm{MeOH}$ then scanned between $400-800 \mathrm{~nm}$ to get maximum absorption wavelength to be used to measure the absorbance of sample after being mixed with DPPH solution. Each sample diluted with $\mathrm{MeOH}$ to make the concentration of methanolic extracts $500,250,125$ and 62.5 ppm; hexane 2000, 1000, 500 and 250 ppm; EtOAc $125,62.5,31.25$ and 15.625 ppm; $\mathrm{BuOH} 250,125,62.5$ and $31.25 \mathrm{ppm}$; pure isolated compounds as well as control gallic acid and ascorbic acid were prepared at the concentration of $50,25,12.5,6.25$ and $3.125 \mathrm{ppm}$. Each extract, fraction and isolated compound as well their dilution was pipetted $0.2 \mathrm{~mL}$ and mixed with $3.8 \mathrm{~mL}$ DPPH solution. The absorbance of mixing solutions was measured 30 min after the reaction. Data obtained were processed by using Finey Program and then corrected with regression equation.

\section{RESULT AND DISCUSSION}

\section{Isolated Compounds}

Compound (1) was obtained as reddish brown plates and gave molecular ion at $\mathrm{m} / \mathrm{z} 154.0267$ which was suitable with molecular formula $\mathrm{C}_{7} \mathrm{H}_{6} \mathrm{O}_{4}$. IR spectrum of (1) showed absorptions at $\left(\mathrm{cm}^{-1}\right) 3210.73$ (broad, OH); 1675.42 (C=O carboxylate); 1299.78 (C$\mathrm{H}) ; 1096.45(\mathrm{C}=\mathrm{C}) ; 764.7(\mathrm{C}=\mathrm{C}-\mathrm{H})$. The presence of aromatic ring was supported by the UV data $\left(\lambda_{\text {maks }}\right.$ 294.2 and $258.0 \mathrm{~nm}$ ). Both of isolated compounds gave dark blue color when treated with ferric chloride indicated the presence of phenolic hydroxyl function. The $6{ }^{13} \mathrm{C}$ atom signals between $114-151 \mathrm{ppm}$ also indicated the presence of aromatic ring. Signal at $170.38 \mathrm{ppm}$ was due to carbonyl function of carboxylate. ${ }^{1} \mathrm{H}-\mathrm{NMR}$ clearly indicated the presence of 3 protons coupled to each other either attached to C3, $\mathrm{C} 5$ and $\mathrm{C} 6$ with coupling constants $\mathrm{J}_{3.6}=2 \mathrm{~Hz}$ and $\mathrm{J}_{5.6}=$ $6 \mathrm{~Hz}$ (see Fig. 2, Fig. 3 and Table 1) or attached to C2, 5,6 with the same coupling constants. The long range coupling of $\mathrm{C} 1(123.28 \mathrm{ppm})$ in the HMBC experiment can be observed to $\mathrm{H} 6$ (6.79 ppm) and to $\mathrm{H} 2$ (7.44 $\mathrm{ppm}$ ) which was slightly hindered by the signals of $\mathrm{H} 5$ (7.42 ppm) (see Fig. 1). Other HMBC correlation of C3$\mathrm{H} 2, \mathrm{C} 4-\mathrm{H} 5, \mathrm{C} 5-\mathrm{H} 6$ as well as long range coupling of $\mathrm{C}$ carbonyl to $\mathrm{H} 2$ and $\mathrm{H} 6$ can also be observed clearly. Thus, based on these available data if the position of the carboxyl group was at $\mathrm{C} 1$, the protons of these compounds should be attached to $\mathrm{C} 2, \mathrm{C} 5$ and $\mathrm{C} 6$ and the two hydroxyl functions attached to $\mathrm{C} 3$ and $\mathrm{C} 4$. This compound could be identified as 3,4-dihydroxybenzoic acid (protocatechuic acid). Further comparison to physical data of this compound to that of reported data of 3,4-dihydroxybenzoic acid (1) in the literature [9] and to that of 2,4-dihydroxybenzoic acid [18] confirmed the above identification.

Compound (2) was obtained as a colorless needle and gave molecular ion at $\mathrm{m} / \mathrm{z} 138.0318$ and was considered to have molecular formula $\mathrm{C}_{7} \mathrm{H}_{6} \mathrm{O}_{3}$. IR spectrum of (1) showed absorptions at $\left(\mathrm{cm}^{-1}\right) 3238.70$ $(\mathrm{OH}), 1651.83(\mathrm{C}=\mathrm{O}$ aldehyde), 1589.94 and 1455.25 (C=C aromatic), 1304.50 (C-H aldehyde), 1154.17 (O$\mathrm{H}), 877.70$ and $814.16(\mathrm{C}-\mathrm{H}), 776.70(\mathrm{C}=\mathrm{C})$ and 755.42 $\mathrm{cm}^{-1}(\mathrm{C}=\mathrm{C})$. The presence of aromatic ring was supported by the UV absorption data $\left(\lambda_{\text {maks }} 312.2\right.$, $278.2 \mathrm{~nm})$. The ${ }^{13} \mathrm{C}$-NMR signals indicated the presence of benzene ring, signals at 190.02 due to carbonyl of aldehyde. ${ }^{1} \mathrm{H}$-NMR clearly indicated the presence of 3 protons coupled to each other at position 2, 5, 6 with coupling constants $J_{2.6}=2 \mathrm{~Hz}$, and $J_{5.6}=6$ Hz. (see Fig. 4, Fig. 5 and Table 1). As above this compound was identified as 3,4dihydroxybenzaldehyde (2) [9]. 


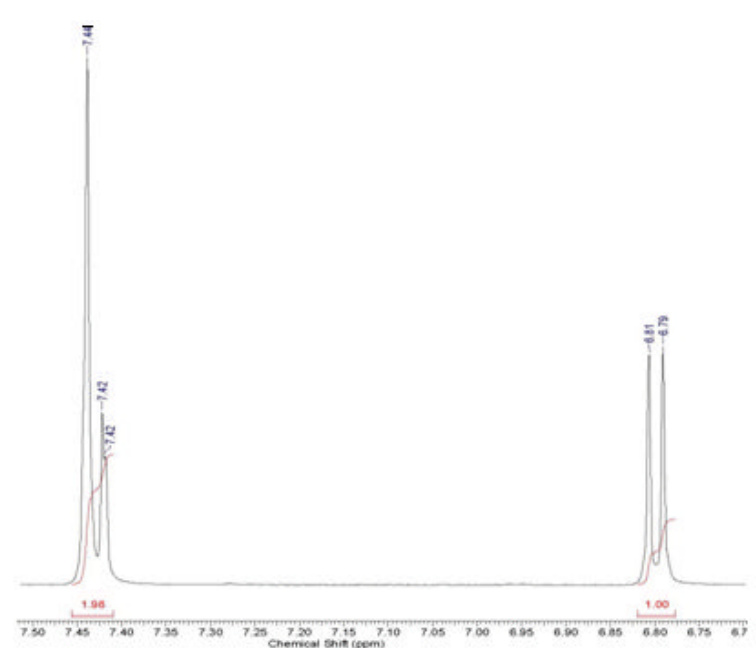

Fig 2. Spectrum ${ }^{1} \mathrm{H}-\mathrm{NMR}$ compound (1)

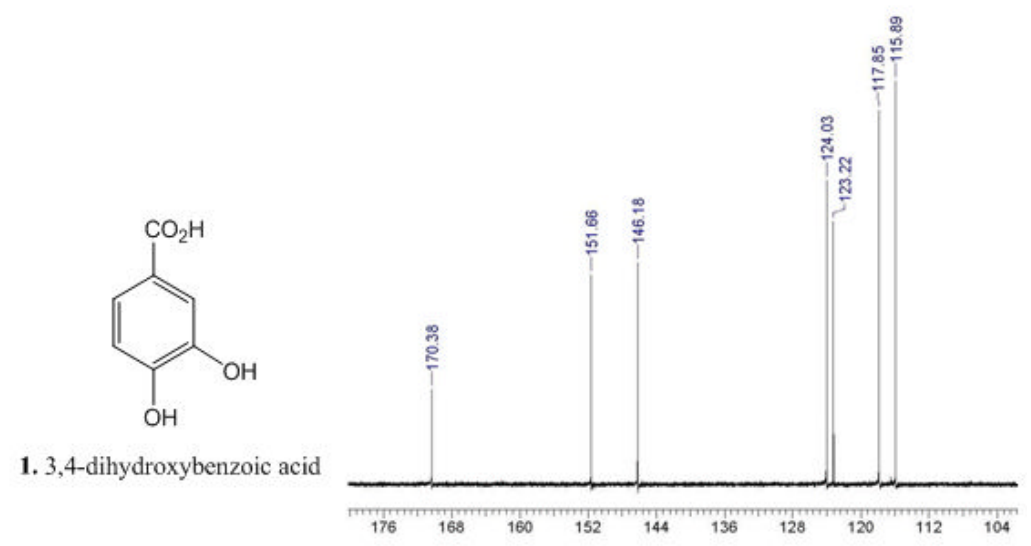

Fig 3. Spectrum ${ }^{13} \mathrm{C}-\mathrm{NMR}$ compound (1)

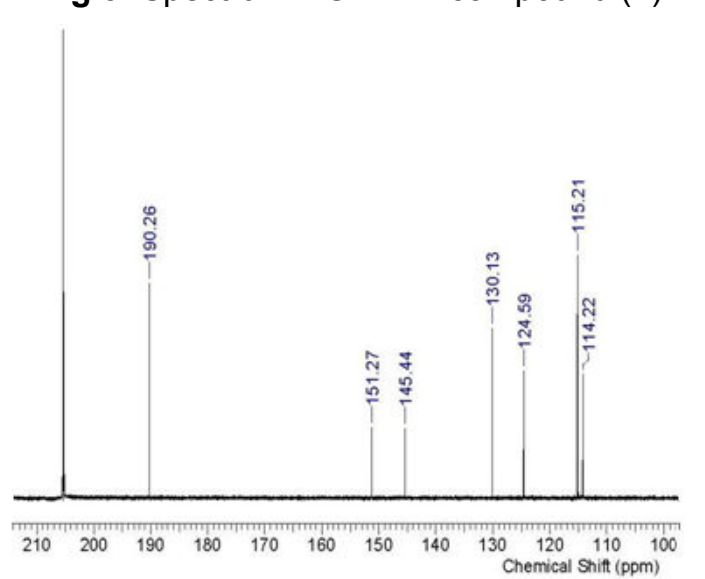

Fig 5. Spectrum ${ }^{13}$ C-NMR compound (2)
Fig 4. Spectrum ${ }^{1} \mathrm{H}-\mathrm{NMR}$ compound (2)

\section{Antimicrobial Properties}

The antimicrobial potency of extracts and fractions of leaves stems and roots as well as two isolated compounds of $T$. chinense L. toward E. coli ATCC 25922 NCTC 1224, Staphylococcus aureus ATCC 25923, Vibrio cholera Inaba and Salmonella thypimurium ATCC 14028 NCTCC 12023 showed significant and dosedependent inhibition towards used testing microbes (see Table 2). This result supports the traditional use of this plant to treat diarrhea. The experiments also revealed that the extracts and isolated compounds also active against Salmonella thypimurium ATCC 14028 NCTCC 12023 which was not only caused diarrhea but also salmonellosis with fever and abdominal cramp additional symptoms.

Interestingly at the working dose, antimicrobial activities of isolated compound (1) and (2) toward Escherichia coli ATCC 25922 NCTC 1224 was not significant compared to those of other testing bacteria, while extracts and fractions still showed significant inhibitions compared to that of chloramphenicol. This means that even though the major compounds were not active there might be other minor active constituents present in the extracts and fractions. Our experiments also showed that the isolated compounds significantly inhibited the growth of Vibrio cholera but not significantly affected Escherichia coli which mean the extracts still can be used to treat diarrhea at the higher dose.

Previous study on ethanolic extract of the flower of roselle (Hibiscus sabdariffa) that consists of protocatechuic acid as well as pure isolated protocatechuic acid showed their potential for food additive at the dose dependent to prevent the contamination of spoilage bacteria such as Salmonella typhimurium DT104, Escherichia coli 0157:H7, Listeria monocytogenes, Staphylococcus aureus, and Bacillus cereus [19]. Compound (2) was found to inhibit the growth of fungus Gloeosporium musarum which causes the ripe of banana fruit to rot [20]. 
Table 2. Antimicrobial properties of extracts, fractions, two isolated compounds and chloramphenicol

\begin{tabular}{|c|c|c|c|c|c|}
\hline \multirow[b]{2}{*}{ No. } & \multirow[b]{2}{*}{ Sample } & \multicolumn{4}{|c|}{ Zone Inhibition (mm) (mg extract/disc) } \\
\hline & & Escherichia coli & Vibrio cholera & $\begin{array}{c}\text { Staphylococcus } \\
\text { aureus }\end{array}$ & $\begin{array}{c}\text { Salmonella } \\
\text { thypimurium }\end{array}$ \\
\hline 1. & Methanolic extr. leaves & $7\left(0.5^{\mathrm{a}}\right)$ & $7.5\left(0.125^{\mathrm{a}}\right)$ & $7\left(0.0625^{a}\right)$ & $7\left(0.25^{\mathrm{a}}\right)$ \\
\hline 2. & Methanolic extr. stems & $10\left(0.25^{\mathrm{a}}\right)$ & $7\left(0.25^{\mathrm{a}}\right)$ & $6\left(0.5^{\mathrm{a}}\right)$ & $7\left(0.25^{\mathrm{a}}\right)$ \\
\hline 3. & Methanolic extr. roots & $7\left(0.5^{\mathrm{a}}\right)$ & $7\left(0.125^{\mathrm{a}}\right)$ & $7\left(0.25^{\mathrm{a}}\right)$ & $7\left(0.5^{\mathrm{a}}\right)$ \\
\hline 4. & Hexane fr. leaves & $6\left(0.5^{a}\right)$ & $7\left(0.5^{\mathrm{a}}\right)$ & $6\left(2^{a}\right)$ & $7\left(1^{a}\right)$ \\
\hline 5. & Hexane fr. stems & $6.5\left(0.5^{\mathrm{a}}\right)$ & $7\left(0.5^{a}\right)$ & $6\left(2^{a}\right)$ & $7\left(0.25^{\mathrm{a}}\right)$ \\
\hline 6. & Hexane fr. roots & $6\left(0.5^{\mathrm{a}}\right)$ & $7\left(0.5^{a}\right)$ & $8\left(1^{a}\right)$ & $7\left(0.25^{\mathrm{a}}\right)$ \\
\hline 7. & EtOAc fr. leaves & $7\left(0.25^{\mathrm{a}}\right)$ & $8\left(0.125^{a}\right)$ & $8\left(0.25^{\mathrm{a}}\right)$ & $8\left(0.25^{\mathrm{a}}\right)$ \\
\hline 8. & EtOAc fr. stems & $7\left(0.25^{\mathrm{a}}\right)$ & $7\left(0.125^{a}\right)$ & $6\left(0.5^{\mathrm{a}}\right)$ & $7\left(0.125^{\mathrm{a}}\right)$ \\
\hline 9. & EtOAc fr. roots & $6.5\left(0.25^{a}\right)$ & $8\left(0.125^{a}\right)$ & $7\left(0.25^{a}\right)$ & $6\left(0.25^{\mathrm{a}}\right)$ \\
\hline 10. & $\mathrm{BuOH}$ fr. leaves & $6\left(1^{\mathrm{a}}\right)$ & $7\left(0.125^{a}\right)$ & $6.5\left(0.25^{a}\right)$ & $6\left(1^{a}\right)$ \\
\hline 11. & $\mathrm{BuOH}$ fr. stems & $6\left(0.5^{\mathrm{a}}\right)$ & $6\left(0.125^{a}\right)$ & $7\left(0.25^{\mathrm{a}}\right)$ & $6\left(1^{a}\right)$ \\
\hline 12. & $\mathrm{BuOH}$ fr. roots & $6\left(0.5^{\mathrm{a}}\right)$ & $8\left(0.125^{a}\right)$ & $6\left(0.5^{a}\right)$ & $6\left(1^{a}\right)$ \\
\hline 13. & Compound 1 & $-\left(2.5^{b}\right)$ & $7\left(2.5^{b}\right)$ & $5.5\left(2.5^{b}\right)$ & $10\left(2.5^{\mathrm{b}}\right)$ \\
\hline 14. & Compound 2 & $5.5\left(2.5^{\mathrm{b}}\right)$ & $6\left(2.5^{b}\right)$ & $5.5\left(2.5^{\mathrm{b}}\right)$ & $8\left(1.25^{\mathrm{b}}\right)$ \\
\hline 15. & Chloramphenicol & $6.8 \pm 0.5(0.3)^{\mathrm{b}}$ & $10.4 \pm 2(0.3)^{b}$ & $6.5 \pm 0.8(0.3)^{b}$ & $8.3 \pm 0.6(0.3)^{b}$ \\
\hline
\end{tabular}

(a) concentration in $\mathrm{mg} / \mathrm{disc}$

(b) concentration in $\mu \mathrm{g} / \mathrm{disc}$

Table 3. Data of antioxidant properties showed in concentration reaction

\begin{tabular}{llll}
\hline \multirow{2}{*}{ Sample } & \multicolumn{3}{c}{$\mathrm{IC}_{50}(\mathrm{ppm})$} \\
\cline { 2 - 4 } & Leaves & Stems & Roots \\
\hline MeOH extr. & 5.83 & 4.52 & 5.15 \\
Hexane fr. & 14.32 & 31.35 & 25.63 \\
EtOAc fr. & 1.33 & 1.57 & 1.52 \\
& & & $(1.78)^{*}$ \\
BuOH fr. & 3.96 & 4.49 & 5.23 \\
& & & $(6.69)^{*}$ \\
\hline
\end{tabular}

${ }^{*}$ corrected with regression equation

Table 4. Data of antioxidant properties showed in concentration reaction

\begin{tabular}{clc}
\hline No. & \multicolumn{1}{c}{ Sample } & $\mathrm{IC}_{50}(\mathrm{nM})$ \\
\hline 1. & Compound 1 & 0.86 \\
2. & Compound 2 & 0.58 \\
3. & Gallic acid & 0.86 \\
4. & Ascorbic acid & 1.57 \\
\hline
\end{tabular}

\section{Antioxidant Properties}

Antioxidant screening of extracts and fractions of leaves, stems and roots of $T$. chinense showed the potential antioxidant properties in all of extracts and fractions (see Table 3). The highest antioxidant properties were showed by ethyl acetate fraction of methanolic extract of the leaves. Based on these results, further work was focused on the isolation of major constituents of the EtOAc fraction of leaves, stems and roots. Compound (1) showed significant antioxidant activity at 1.8 times stronger than ascorbic acid and about the same strength as gallic acid. Compound (2) was 2.7 times more potent than ascorbic acid and 1.5 times than gallic acid (see Table 3). The significant antioxidant activity can be understood due to the presence of electronegative carbonyl function of carboxylic and aldehyde attached to $\mathrm{C} 1$ which facilitates the reductive ability of phenolic hydroxyl at C4.

In vitro mechanism of antioxidant activity of compound (1) has been reported using various antioxidant assay. From the results of this assay the effect as chemopreventive agent toward various cancer cells can be estimated. The strongest effect was observed toward skin squamous cell papilloma (PAP) at the doses $5,10,20 \mu \mathrm{M} /$ locally on the skin of mice 5 min before being induced with 12-Otetradecanoylphorbol 13-acetate (TPA) and transitional cell carcinoma (TCC) on buccal pouch of male Syrian golden hamster at the dose of $200 \mathrm{ppm}$ in diet using 7,12-dimethylbenz[ $\alpha]$ anthracene (DMBA) as cancer promoter [21].

\section{CONCLUSION}

The isolation of constituents of ethyl acetate fraction of leaves, stems and roots gave the same major constituents identified as 3,4-dihydroxybenzoic acid and 3,4-dihydroxybenzaldehyde. The antimicrobial properties of extracts, fractions and compounds (1) and (2) support the traditional use of the fern $T$. chinense to treat diarrhea, while their strong antioxidant properties might be developed into further use.

\section{ACKNOWLEDGEMENT}

We are grateful to DP2M-DIKTI-Kemendiknas "Hibah Kompetensi 2008-2010" (to DA) for supporting the preliminary study of Trichomanes chinense. We thank Mr. Friardi and Pr. Joel Boustie from UMR 6226 
Sciences Chimiques de Rennes, Equipe Produits Naturels Synthèses Chimie Médicinale, Universite de Rennes 1, France, for MS and NMR spectroscopic data; Dr. Ardinis Arbain from Andalas University Herbarium (ANDA) and Dr. Arif Hidayat from Herbarium Bogoriense (BO) for identification of the fern specimen; Indonesian Food and Drug Administration (BPOM) Padang for providing testing microbes.

\section{REFERENCES}

1. Preston, R.D., and Woolhause, H.W., "Advances in Botanical Research Vol. 4" in Evalutionary Patterns and Processes in Ferns., Lovis, J.D., Academic Press, London, New York, San Fransisco, 1977, 229-402.

2. Ardaka, I.M., Sudiatna, I.N., and Sukedana, I.K., 2005, Eksplorasi Tumbuhan Paku Potensial Kawasan Timur Indonesia di Kabupaten Jembrana. Bali: Kebun Raya 'Eka Karya' Bali-LIPI, 50-54.

3. Hartini, S., 2006, Biodiversitas, 7, 3, 230-236.

4. Jubahar, J., Dachriyanus, Arbain, D., Bakhtiar, A., Mukhtar, M.H., and Sargent, M.V., 2006, ACGC Chem. Res. Commun., 20, 6-7.

5. Fernandez, H., Kumar, A., and Revilla, M.A., "Working with Ferns Issues and Applications", in Studies on Folk Medicinal Fern: An Example of GuSui-Bu, Chang, H-C., Gupta, S.K. and Tsay, H-S., Springer Science Business Media, New York, Dordrech, Heidelberg, London, 2011, 285-302.

6. Syafni, N., Rachmawati, V., Yenita, M., Putra, D.P. and Arbain, D., 2011, Proceedings, International Symposium on Natural Products and their Applications in Health and Agriculture, Institute of Fundamental Studies, Kandy, Sri Lanka, 91.

7. Hutapea, J.R., "Inventaris Tanaman Obat Indonesia (III)", Departemen Kesehatan RI; Badan Penelitian dan Pengembangan Kesehatan, Jakarta, 1994, 910.

8. Badan Penelitian dan Pengembangan Kesehatan, "Inventaris Tanaman Obat Indonesia (V)", Departemen Kesehatan RI, Jakarta, 23-24, 47-48, 107-108, 115-120, 125-128, 133-136, 171-172, 187-192.

9. Naji, N.A., Shaari, K., Abas, F., and Lajis N.H., 2009, ACGC Chem. Res. Comm., 23, 44-47.

10. Li, X., Wang, X., Chen, D., and Chen, S., 2011, Funct. Foods Health Disease, 1, 7, 232-244.

11. Zhao, H.R., Wang, M.S., and Zhou, G.P., 1993, Zhongguo Zhong Yao Za Zhi., 18, 4, 226-8, 255.

12. Tseng, T-H., Kao, T-W., Chu, C-Y., Chou, F-P., Lin, W-L., and Wang, C-J., 2000, Biochem. Pharmacol., 60, 307-315.

13. Chang, Z.Q., Gebru, E., Lee, S.P., Rhee, M.H., Kim, J.C., Cheng, H., and Park, S.C., 2011, J. Nutr. Sci. Vitaminol, 57, 1, 118-122.

14. Zhang, Y., Huang, B., Zhao, Z., and Zhou, Y., 2011, Zhong Yao Cai, 34, 12,1882-3.

15. Weber, B., Hoesch, L., and Rast, D.M., 1995, Phytochem., 40, 2, 433-437.

16. Chen, I-N., Chang, C-C., Ng, C-C., Wang, C-Y., Shyu Y-T., and Chang, T-L., 2008, Plant Foods Hum. Nutr., 63, 1, 15-20.

17. Molyneux, P., 2004, Songklanakarin J. Sci. Technol., 26, 2, 211-219.

18. Li, N., Li, X., Feng, Z., Li, X., and Zhang, P., 2007, Zhongcaoyao, $\left(\right.$ SciFinder $^{\circledR}$, accessed on January 2012).

19. Chao, C-Y., and Yin, M-C., 2008, Foodborne Pathog Dis., In press, DOI: $10.1089=$ fpd. 2008.0187.

20. Mulvena, D., Webb, E.C., and Zerner, B., 1969, Phytochem., 8, 2, 393-395.

21. Tanaka, T., Tanaka, T., and Tanaka, M., 2011, J. Exp. Clin. Med., 3, 1, 27-33. 